\title{
Regulation of Smooth Muscle Cell Scavenger Receptor Expression In Vivo by Atherogenic Diets and In Vitro by Cytokines
}

\author{
Hongmei Li, ${ }^{\star \S}$ Mason W. Freeman, ${ }^{\star}$ and Peter Libby $\$$ \\ *Vascular Research Division, Department of Pathology, and ${ }^{8}$ Vascular Medicine and Atherosclerosis Unit, Cardiovascular Division, \\ Department of Medicine, Brigham and Women’s Hospital, Boston, Massachusetts 02115; and ${ }^{\ddagger}$ Department of Medicine, Lipid \\ Metabolism Unit, Massachusetts General Hospital, Boston, Massachusetts 02114
}

\begin{abstract}
Scavenger receptor (ScR)-mediated uptake of modified lipoproteins may contribute to the transformation of smooth muscle cells into lipid-laden foam cells during atherogenesis. This study examined the in vivo expression of ScRs in aortas, with or without balloon injury, taken from hypercholesterolemic or normocholesterolemic rabbits. Numerous intimal cells in the rabbit aortic lesions expressed ScRs as detected by immunocytochemical staining with a goat anti-rabbit ScR antibody. Single immunostaining for cell identification markers in serial sections, as well as double staining, confirmed the expression of ScRs by both intimal smooth muscle cells and macrophages. To explore potential inducers of ScR expression by smooth muscle cells in vivo, we studied the regulation of ScR expression in vitro by cytokines known to be present in atherosclerotic lesions. Tumor necrosis factor- $\alpha$ (TNF- $\alpha$ ) or interferon- $\gamma($ IFN- $\gamma$ ) increased ScR mRNA levels, protein expression, and AcLDL degradative activity in cultured rabbit aortic smooth muscle cells. The induction of ScR expression in intimal smooth muscle cells in vivo could be a useful marker of smooth muscle cell activation during atherogenesis and may contribute to foam cell formation by this cell type following balloon injury and/ or hypercholesterolemia. Cytokines, such as TNF- $\alpha$ or IFN- $\gamma$, may stimulate some of the phenotypic changes that characterize the alteration in gene expression of intimal smooth muscle cells in rabbit atherosclerotic lesions. (J. Clin. Invest. 1995. 95:122-133.) Key words: scavenger receptor • smooth muscle cells - atherosclerosis - rabbit - balloon injury
\end{abstract}

\section{Introduction}

The accumulation of lipid-laden foam cells, derived from macrophages and smooth muscle cells, is one of the characteristic

Some of the data contained in this report were presented at the 65th Scientific Sessions of American Heart Meeting, November 1993. (Regulation of smooth muscle cell scavenger receptor expression in vivo by atherogenic diet and in vitro by cytokines. Circulation. 88:2499a [Abstr.]).

Address correspondence to M. W. Freeman, Department of Medicine, Bulfinch 051, MGH, Boston, MA, 02114. Phone: 617-726-5906; FAX: 617-726-2879.

Received for publication 25 May 1994 and in revised form 16 September 1994

J. Clin. Invest.

(C) The American Society for Clinical Investigation, Inc.

$0021-9738 / 95 / 01 / 0122 / 12 \quad \$ 2.00$

Volume 95, January 1995, 122-133 early changes in the arterial intima of a developing atherosclerotic plaque (1-4). Although a detailed understanding of the process leading to the transformation of macrophages and smooth muscle cells into foam cells is not available, this process appears to involve receptor-mediated uptake of cholesterol-rich particles $(1,5)$. As the binding of native low density lipoproteins (LDL) to the LDL receptor in vitro does not result in foam cell formation, alternative receptor pathways were sought to account for this phenomenon (6). The identification of a new type of lipoprotein receptor, the acetyl-LDL or scavenger receptor $(\mathrm{ScR}),{ }^{1}$ provided a candidate protein whose activity could mediate the formation of foam cells $(5,7)$.

Scavenger receptors are integral membrane proteins that bind and internalize a broad array of ligands, including acetylated and oxidized LDL. Unlike the LDL receptor, their activity is not suppressed by rising intracellular cholesterol concentrations, thus providing a mechanism for massive cholesterol uptake. Nonmacrophage cells transfected with cDNAs encoding scavenger receptors accumulate cholesterol and develop a foam cell appearance when incubated with modified LDL, whereas mock-transfected cells do not (8). These findings suggested that the expression of scavenger receptor protein might be both necessary and sufficient to account for foam cell formation in vivo.

ScR cDNAs have now been cloned from bovine, human, murine, and rabbit sources (9-13). Two cDNAs, encoding a type I receptor and a shorter type II receptor, have been identified in all four species. Both type I and type II receptors are glycoproteins that bind their ligands (e.g., AcLDL) with high affinity, apparently via a collagen-like domain in the extracellular carboxyl-terminal portion of the molecule $(14,15)$. Both receptors have been found in macrophage cell lines and macrophage-rich tissues, including atherosclerotic plaques (16-18). The immunohistochemical demonstration of ScR expression in macrophage-derived foam cells at various stages of atherosclerosis strengthens the evidence that they contribute to the transformation of macrophages into foam cells during atherogenesis.

During atherogenesis, certain subpopulations of smooth muscle cells undergo structural and functional changes, one consequence of which can be their transformation into foam cells. These altered intimal smooth muscle cells display phenotypic features not seen in normal medial smooth muscle cells $(19,20)$. Earlier studies have reported the expression of scavenger receptor activity in smooth muscle cells isolated from atherosclerotic lesions of rabbit aorta, whereas medial smooth muscle cells did not express this activity $(21,22)$. While the regulation of ScR expression in macrophages by factors thought to be present in the atherogenic process has been the object of

1. Abbreviation used in this paper: ScR, scavenger receptor. 
considerable investigation (23-26), much less is known about this same process in smooth muscle cells. Two recent studies showed that cultured medial smooth muscle cells of rabbit aorta inducibly express macrophage ScR mRNA following stimulation with phorbol esters $(13,27)$. These observations suggest that phenotypic modulation or activation of smooth muscle cells may induce $\mathrm{ScR}$ expression as part of a more general program of altered gene expression. Such alteration in gene expression, that distinguishes the intimal from medial smooth muscle cell, may contribute both to the formation of smooth muscle cellderived foam cells in atherosclerotic lesions and to the subsequent development of complex, fibrotic plaques.

The present study presents evidence that a subpopulation of intimal smooth muscle cells in rabbit atherosclerotic lesions express the ScR in vivo, whereas smooth muscle cells in the adjacent arterial media do not. This work also demonstrates that cytokines TNF- $\alpha$ and IFN- $\gamma$, both of which are produced locally in atherosclerotic lesions, can increase the expression of ScRs by rabbit vascular smooth muscle cells in vitro.

\section{Methods}

Animals. 10 Male New Zealand white, Pasteurella-free rabbits (Millbrook Farms, Amherst, MA), weighing FF7E3 kg were used throughout the study. The rabbits were housed in individual cages. Diet and water were provided ad libitum. Five rabbits consumed a normal rabbit chow diet while the other five consumed a hypercholesterolemic chow diet that contained $0.5 \%$ cholesterol and $4.5 \%$ hydrogenated coconut oil. At the end of the sixth week on the diets, the animals were anesthetized with ketamine $(35 \mathrm{mg} / \mathrm{kg})$ and xylazine $(7 \mathrm{mg} / \mathrm{kg})$ by intramuscular injection. Balloon injury to the abdominal aortas was performed as previously described using a Fogarty $3 \mathrm{~F}$ balloon catheter (Baxter Hospital Supply, Edison, NJ) (28). $10 \mathrm{~d}$ after balloon injury, the rabbits were killed and the aortas were removed. Segments from the injured area of the abdominal aorta and a portion of the thoracic aorta in the uninjured area were snap-frozen in isopentane, cooled in liquid nitrogen.

Isolation, characterization, and culture of rabbit aortic smooth muscle cells. Rabbit aortic smooth muscle cells were isolated using an explant technique as described previously $(29,30)$. Briefly, cells were cultured in Dulbecco's Modified Eagle's Medium with $10 \%$ fetal bovine serum, $100 \mathrm{U} / \mathrm{ml}$ penicillin, $100 \mathrm{mg} / \mathrm{ml}$ streptomycin, and $2 \mathrm{mM} \mathrm{L}$ glutamine. At confluence, cells were passaged with $0.2 \%$ trypsin and were used between passages 2 and 5 (FF7E1 wk/passage). All components used in tissue culture media were tested for endotoxin contamination using the chromogenic Limulus amebocyte lysate assay (Bioproducts, Walkersville, MD) and yielded a final concentration of endotoxin less than $40 \mathrm{pg} / \mathrm{ml}$.

Antibodies and reagents. Goat anti-serum recognizing both the type I and type II rabbit scavenger receptors was raised by injection of a synthetic peptide of 17 amino acids, corresponding to the sequence of the $\mathrm{NH}_{2}$-terminal domain of the rabbit ScR, coupled to keyhole limpet hemocyanin. The sequence of the synthetic peptide was MAQWDSFTDQQEDTDSC (kindly synthesized by the Endocrine Unit Peptide Core, Massachusetts General Hospital). Other antibodies used in this study include monoclonal antibody (mAb) HHF35 (mouse IgG1; Enzo Diagnostic, Inc., New York, NY), which recognizes smooth muscle $\alpha$-actin (31), mAb RAM-11 (mouse IgG1, provided by Dr. Gown, University of Washington, Seattle, WA) which recognizes an uncharacterized cytoplasmic antigen protein of rabbit macrophages (32), and mAb L11/135 (mouse IgG1) which recognizes a $120-\mathrm{kD}$ glycoprotein determinant present on rabbit thymocytes and peripheral $\mathrm{T}$ cells (American Type Culture Collection, Rockville, MD). Rabbit recombinant interleukin (IL) 1- $\alpha$ (Glaxo, England), rabbit recombinant tumor necrosis factor (TNF)$\alpha$ (Scripps Clinic and Research Foundation, San Diego, CA), rabbit recombinant interferon (IFN)- $\gamma$ (Genentech, San Francisco, CA), and lipopolysaccharide (LPS) (Escherichia coli, 055:B5, Sigma Chemical Co., St. Louis, MO) were used in the tissue culture studies.

Western blotting. cDNAs encoding the bovine or the rabbit type II receptor, with or without a rhodopsin epitope tag (33), were transfected into COS cells in the expression vector pCDNA-1 as previously described (13). Mock-transfected COS cells were transfected with pCDNA-1, containing no inserted DNA. $48 \mathrm{~h}$ after transfection, cells in 100 -mm dishes were lysed in either 0.63 or $1.26 \mathrm{ml}$ of lysis buffer (phosphate buffered saline, 1\% Triton X-100, $1 \mathrm{mM}$ PMSF and $0.1 \mathrm{mM}$ leupeptin). $\operatorname{COS}$ cell lysates were subjected to electrophoresis on a $4 \%$ stacking/8\% separating SDS polyacrylamide gel in a Bio-Rad miniProtean II apparatus (Bio Rad Laboratories, Richmond, CA). Rabbit $\mathrm{ScR} /$ human IgG fusion proteins, lacking the amino acids comprising the peptide used to raise the goat anti-serum but containing all the other extracellular domains of the rabbit $\mathrm{ScR}$, were prepared in COS cells, purified by protein A affinity chromatography, and electrophoresed along with the cell lysates. These proteins served as additional negative (anti-ScR antibody) and positive (ID4 antibody) controls for the Western blot procedure. Electrophoretic transfer to nitrocellulose was accomplished at $140 \mathrm{~V}$ for $3 \mathrm{~h}$ at $4^{\circ} \mathrm{C}$ in $25 \mathrm{mM}$ Tris, $\mathrm{pH} 8.3,192 \mathrm{mM}$ glycine, and $20 \%$ methanol. The membrane was then blocked with $1 \%$ Tween20 and $10 \%$ dried milk in PBS (buffer A) for $1 \mathrm{~h}$ at room temperature (RT). Goat anti-serum against rabbit $\mathrm{ScR}$, diluted $1 / 100$, was added to fresh Buffer A and incubated for $30 \mathrm{~min}$ at RT followed by four washes in Buffer A without milk. A rabbit anti-goat horseradish peroxidase (HPO) labeled antibody (Sigma A5420) was then bound in Buffer A for $30 \mathrm{~min}$ at RT followed by four washes as above. Detection of the peroxidase activity was carried out with $3,3^{\prime}$-diaminobenzidine tetrahydrochloride according to the manufacturer's instructions (Sigma Chemical Co.). The same blotting procedure was conducted using ID4, a monoclonal antibody recognizing the rhodopsin epitope tag (33), substituted for the goat anti-serum, with detection accomplished using a rabbit anti-mouse HPO-labeled second antibody.

Immunohistochemical staining. Immunohistochemical staining was performed as previously described $(34,35)$. Briefly, 6-mm-thick frozen sections from balloon injured or non-injured areas of rabbit aortas were adhered to poly-L-Lysine-coated slides, fixed in cold acetone and incubated with antibodies anti-ScR $(1 / 3,000)$, HHF-35 (1/10), or RAM-11 $(1 / 3,000)$ for $1 \mathrm{~h}$. After washing three times in Tris-buffered saline (145 $\mathrm{mM} \mathrm{NaCl}$ and $5 \mathrm{mM}$ Tris, $\mathrm{pH} 7.4$ ) containing $2 \%$ horse serum, speciesappropriate biotinylated secondary antibodies were applied, followed by avidin-biotin peroxidase complexes (ABC Elite kit; Vector Labs, Burlingame, CA). Antibody binding was visualized with 3-amino-9ethylcarbazole (Sigma Chemical Co.). Sections were counter stained with Gill's hematoxylin. The same method was used to stain rabbit aortic smooth muscle cells cultured in eight-chamber tissue culture slides with or without cytokine stimulation. To evaluate the specificity of the staining, rabbit smooth muscle cells treated with phorbol ester $(100 \mathrm{~nm}$, $24 \mathrm{~h}$ ), a known inducer of ScR expression in smooth muscle cells (13), were used as positive controls and omission of primary antibodies and staining with type- and class-matched nonimmune IgGs were used as negative controls for each antibody used in this study.

Double immunostaining. To confirm the expression of the ScR by intimal smooth muscle cells of the rabbit aorta, we performed double immunostaining on frozen sections. After staining for the smooth muscle cell marker $\alpha$-actin using the ABC peroxidase method as described above (yielding a red peroxidase reaction product), sections were washed in PBS for $5 \mathrm{~min}$ followed by $\mathbf{3 0} \mathrm{min}$ of incubation with avidinbiotin blocking compound (Avidin-Biotin blocking kit; Vector Laboratories). The second primary antibody (goat anti-rabbit ScR) was then applied at $1 / 2,000$ dilution and incubated at $4^{\circ} \mathrm{C}$ overnight. After incubation with biotinylated horse anti-goat antibody, sections were then incubated with alkaline phosphatase avidin-biotin complex (Vecstatin ABC kit, AK-5000; Vector Laboratories) and visualized using Fast Blue (Sigma Chemical Co.), an alkaline phosphate substrate that produces a blue product. Double-stained cells showed mixtures of red (SMC) and 
blue (ScR) colors. Counter staining was not performed on double-stained sections.

Northern blot analysis. Northern blot analysis was performed using standard techniques (36). Total cellular RNA was isolated by centrifugation through a cesium chloride gradient after lysing the cells with $4 \mathrm{M}$ guanidinium isothiocyanate. Equal amounts of RNA were electrophoresed on $1 \%$ agarose gels and transferred to nylon membranes (HybondN; Amersham Corp., Arlington Heights, IL). The blots were hybridized at $42^{\circ} \mathrm{C}$ overnight using a fragment of rabbit ScR cDNA (common to both type I and type II receptors) which was radiolabeled with ${ }^{32} \mathrm{P}$ by random-priming (Pharmacia Inc., Piscataway, NJ). The membrane was washed three times in $2 \mathrm{X} \mathrm{SSC}$ and $0.1 \%$ SDS at $50^{\circ} \mathrm{C}$ for $30 \mathrm{~min}$ and the blots were visualized by autoradiography. The signals on $\mathrm{x}$-ray film were analyzed by densitometry using the National Institutes of Health IMAGE program version 1.49 .

ScR degradative activity assays. The ability of smooth muscle cells to degrade ${ }^{125} \mathrm{I}-\mathrm{AcLDL}(5 \mu \mathrm{g} / \mathrm{ml})$ over $5 \mathrm{~h}$ at $37^{\circ} \mathrm{C}$ in the presence or absence of unlabeled competitors (native LDL or AcLDL, both at 400 $\mu \mathrm{g} / \mathrm{ml}$ ) was assayed as described previously (13). Rabbit aortic smooth muscle cells (passage 3) were cultured in 36-well plates until confluent and were treated in duplicate with control medium, or in medium containing IL-1 $\alpha(10 \mathrm{ng} / \mathrm{ml})$, TNF- $\alpha(10 \mathrm{ng} / \mathrm{ml})$, IFN- $\gamma(1,000 \mathrm{U} / \mathrm{ml})$, or phorbol ester (TPA, $100 \mathrm{~nm}$ ) for $24 \mathrm{~h}$. All lipoproteins used in these assays were prepared by methods previously detailed (37). Iodination of AcLDL was accomplished by a modified iodine monochloride reaction (38).

\section{Results}

Characterization of the goat anti-rabbit ScR antibody. To characterize the specificity of the goat anti-rabbit ScR antibody used in this study, Western blotting of a variety of wild-type and mutant ScR proteins was performed (Fig. 1). The goat antisera recognized ScR proteins in COS cells transfected with wild-type rabbit type II ScR cDNAs, regardless of the presence or absence of a carboxy-terminal rhodopsin epitope tag. The monoclonal antibody (ID4) to the epitope tag bound those proteins which contained the epitope tag but not those which lacked it (data not shown). The bovine type II ScR was not detected with the anti-serum despite the fact that the bovine receptor only differs from the rabbit receptor at 2 positions of the 17 residues present in the hapten. The bovine $S c R$ was readily immunoprecipitated from COS cell lysates with a rabbit antibovine ScR antibody (data not shown), indicating that the bovine receptor was present in the COS cell lysates that were not recognized by the goat anti-rabbit $\mathrm{ScR}$ antibody on the Western blot. Rabbit ScR/human IgG fusion proteins, with or without the epitope tags, also failed to be detected by the goat antiserum. These fusion proteins, which have the $\mathrm{NH}_{2}$-terminal and transmembrane domains of the ScR deleted so that they can be secreted from COS cells, are missing the cytoplasmic sequences used to generate the anti-serum. The failure to detect these proteins in combination with the lack of binding of the antiserum to the lysate of bovine ScR or mock-transfected COS cells, established the specificity of the anti-serum for the rabbit ScR $\mathrm{NH}_{2}$-terminal sequences.

ScR expression by vascular cells in hypercholesterolemic rabbits after balloon injury. We performed immunocytochemical studies to characterize ScR protein expression by vascular cells in aortas from hypercholesterolemic rabbits $10 \mathrm{~d}$ after balloon injury. We chose to use a combination of an atherogenic diet and balloon injury so that we could obtain relatively fibrous (smooth muscle-rich) atheromatous lesions in a relatively short
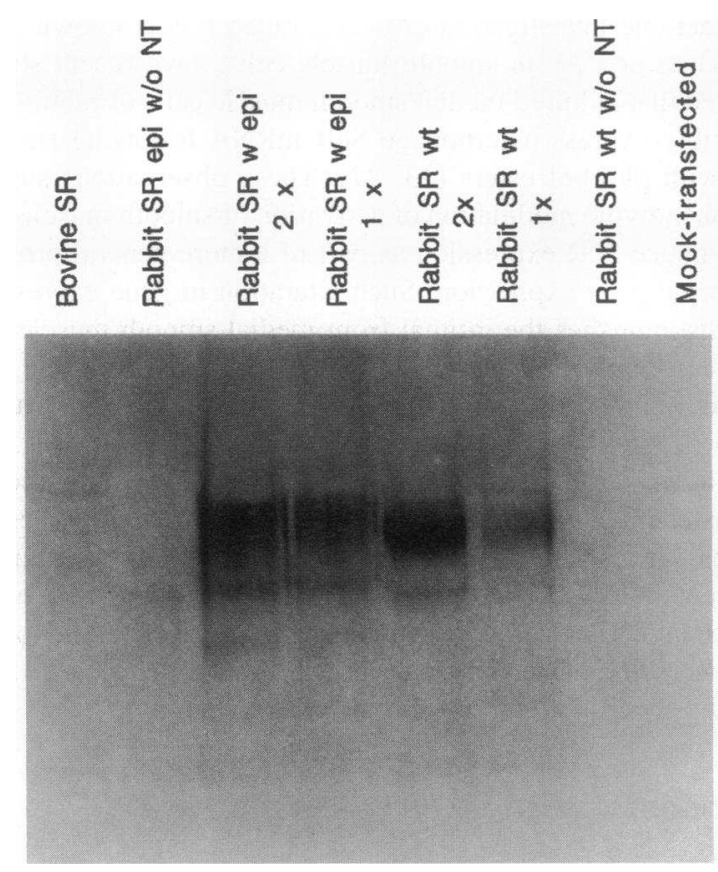

Figure 1. Demonstration of the specificity of goat anti-serum for the rabbit ScR by Western blot. Rabbit and bovine scavenger receptor cDNAs with or without a rhodopsin epitope tag, as well as pCDNA-1 without any insert (mock transfection) were transfected into COS cells. Lysates of transfected COS cells were subjected to Western blotting as described in Methods. Two rabbit ScR/human fusion proteins lacking the ScR sequences used to raise the goat anti-sera, one with and one without the epitope tag, were also immunoblotted on the same gel with the lysates. The blot was labeled from left to the right as follows: Bovine $S R$, lysate of COS cells transfected with bovine ScR cDNA; Rabbit SR epi w/o NT, rabbit $\mathrm{ScR} /$ human fusion protein with epitope tag but no $\mathrm{NH}_{2}$-terminal sequences; Rabbit $S R$ w epi (2X), lysate of COS cells transfected with rabbit ScR CDNA with the epitope tag (2X amount of protein loaded compared to $1 \mathrm{X}$ samples); Rabbit $S R$ w epi (IX), lysate of $\operatorname{COS}$ cells transfected with rabbit ScR CDNA with the epitope tag; Rabbit $S R$ wt (2X), lysate of COS cells transfected with wild type rabbit ScR cDNA without the epitope tag; Rabbit SR wt (IX), lysate of COS cells transfected with wild type rabbit ScR cDNA without the epitope tag; Rabbit SR wt w/o NT, rabbit ScR/human fusion protein without the epitope tag and $\mathrm{NH}_{2}$-terminal sequences; Mock-transfected, lysate of COS cells transfected with PCDNA-1 without any insert.

period of time. Fig. 2 shows representative staining patterns of ScRs and identification markers for smooth muscle cells and macrophages in serial sections obtained from the balloon-injured aorta of a hypercholesterolemic rabbit. Many cells in the intimal lesions, unlike medial cells, reacted with the anti-rabbit ScR antibody (Fig. 2 B), while the same concentration of nonimmune goat serum did not yield any specific staining in the adjacent serial section (Fig. $2 A$ ). Staining with the smooth muscle cell identification marker HHF-35 revealed that a significant portion of intimal smooth muscle cells were located in areas where most ScR expressing cells were present (Fig. $2 C$, arrows). Staining for the macrophage marker RAM-11 showed abundant intimal macrophages in regions both with and without ScR expression, suggesting that some, but not all, intimal macrophages also express ScRs (Fig. $2 \mathrm{D}$ ). At higher magnification, many ScR-expressing cells are spindle-shaped, consistent with 

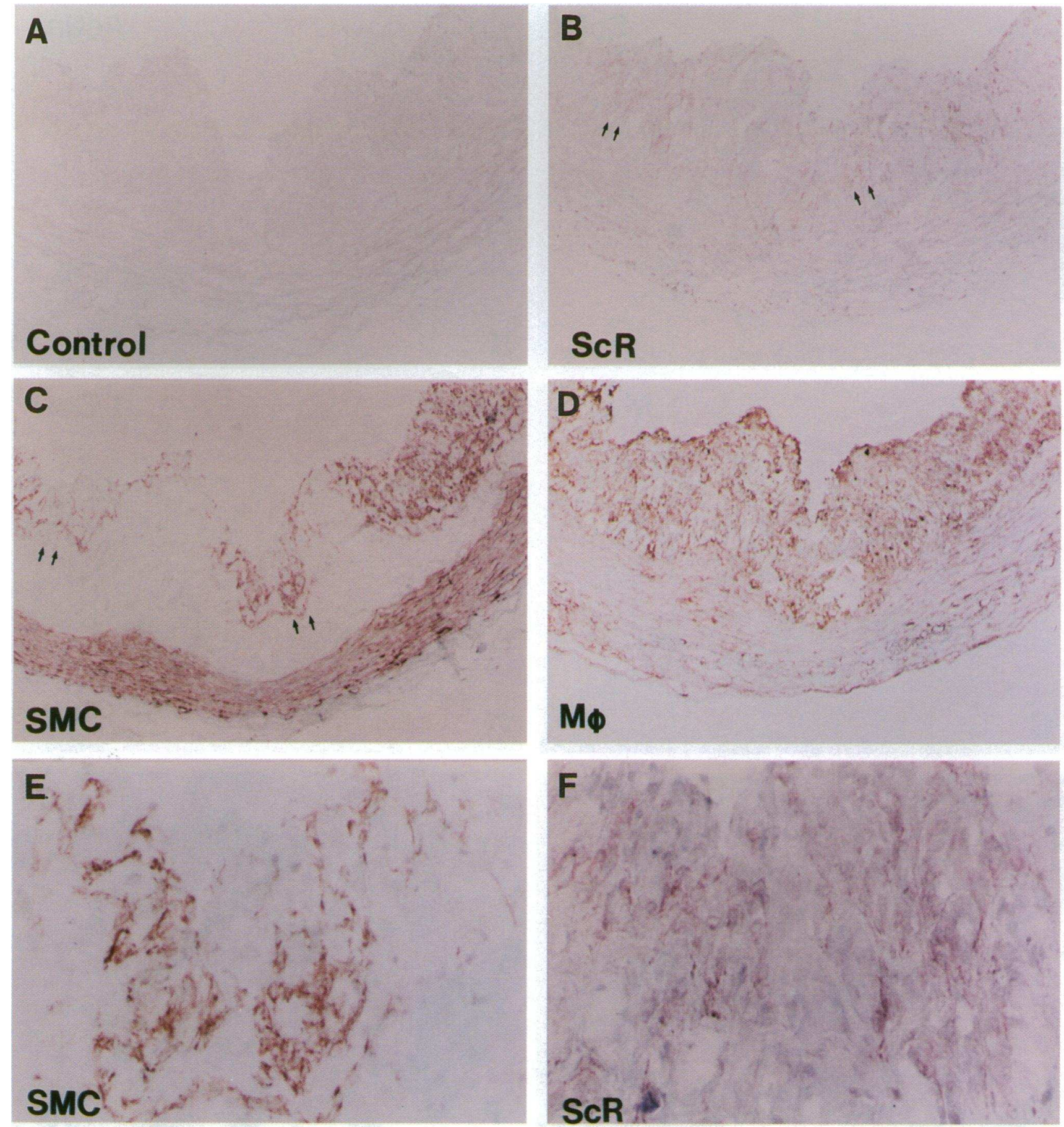

Figure 2. Immunoperoxidase staining for ScR expression and cell type identification markers in serial sections from the balloon-injured aorta of a hypercholesterolemic rabbit. (A) Non- immune goat serum yielded no specific staining. X100. $(B)$ Goat anti-ScR antibody detected ScR expression by intimal cells. X100. (C) Staining for $\alpha$-actin by mAb HHF35 revealed that many smooth muscle cells colocalized spatially with ScR-positive cells (arrows in $B$ and $C$ ). X100. (D) Staining with macrophage marker RAM-11 showed abundant intimal macrophages in areas with or without ScR expression, X100. ( $E$ and $F$ ) Higher power view of arrow-denoted regions in $B$ and $C$ showed that staining for $\alpha$-actin and ScR colocalized in similar areas and that most ScR expressing cells are spindle shaped, consistent with the morphology of intimal smooth muscle cells. X400.

the morphology of intimal smooth muscle cells (Fig. 2, $E$ and $F)$. The typical smooth muscle cell morphology of some ScR positive cells and the colocalization of the $\alpha$-actin and ScR expression in adjacent serial sections suggested that smooth muscle cells might comprise a significant fraction of the intimal
ScR- expressing cells in the lesions of balloon-injured aortas from hypercholesterolemic rabbits. Sections from the other four rabbits in this group revealed similar staining patterns for each antibody.

To verify the origin of the ScR expressing cells, we per- 

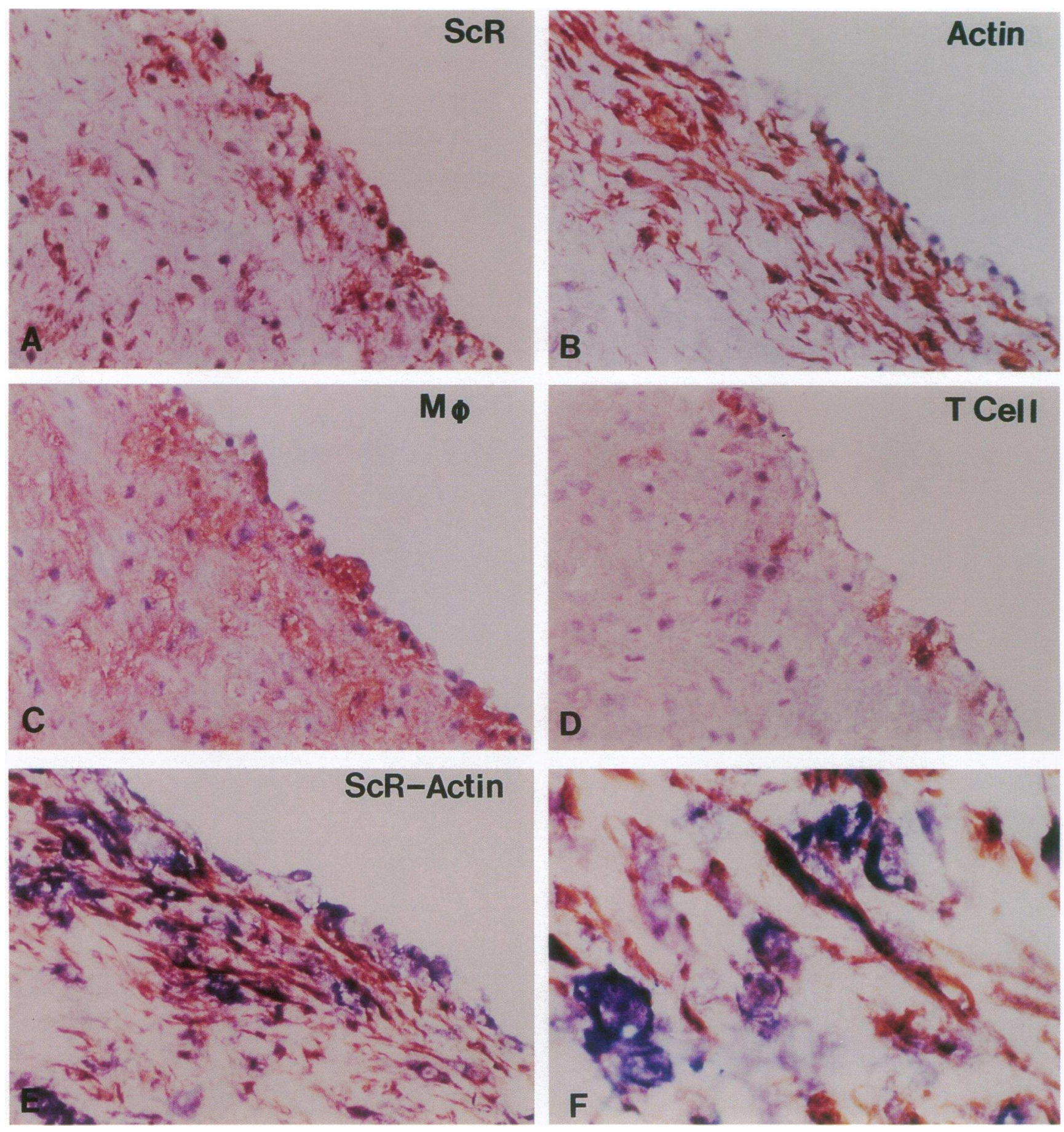

Figure 3. Single and double immunostaining demonstrating that ScRs are expressed by both intimal smooth muscle cells and macrophages in the balloon-injured areas of the aorta from a hypercholesterolemic rabbit. $A D$ show single immunoperoxidase staining for ScR, $\alpha$-actin, macrophages, and T cells respectively in serial sections. X200. (E) Double immunostaining (red, peroxidase staining for $\alpha$-actin; blue, alkaline phosphatase staining for ScR) identified many ScR-expressing intimal smooth muscle cells (mixed red and blue) as well as ScR-expressing macrophages (blue staining only). X200. $(F)$ Higher power view of an area in the double staining section shows the detection of some ScR expressing smooth muscle cells (spindle-shaped cells with two color staining) and ScR-expressing macrophages (round shaped foam cells with blue staining only). X1,000.

formed double-immunostaining on six specimens from three rabbits in the hypercholesterolemic plus balloon injury group (two sections from each animal). Fig. $3, A-D$ shows single immunoperoxidase staining for ScRs, $\alpha$-actin, and macrophages, as well as $\mathrm{T}$ cells in similar regions of serial cross sections from the balloon injured aorta of a hypercholesterolemic rabbit. As in Fig. 2, many ScR expressing cells are present in areas where intimal smooth muscle cells are abundant (i.e., areas just below the lumenal surface, $A$ and $B$ ). Macrophages are detected throughout the entire intimal lesion $(C)$ while $\mathrm{T}$ 
cells are sparsely scattered $(D)$. Double immunostaining (Fig. $3, E$ and $F$ ) demonstrates that many intimal cells express both $\alpha$-actin (red staining) and the ScR (blue staining), identifying these cells as smooth muscle cells that express ScRs. Double staining also revealed that some ScR positive cells are apparently macrophages (cells that only have blue staining for $\mathrm{ScR}$ ) as judged by their morphology (round shaped foam cells) and their nonreactivity with the anti $\alpha$-actin antibody. Staining of serial sections from the other two rabbits showed similar patterns.

ScR expression in non-injured aortas of hypercholesterolemic rabbits. We also performed immunohistochemical studies on serial sections of non-injured areas in the aortas (ascending aortas) from all five hypercholesterolemic rabbits. Staining for $\alpha$-actin (Fig. $4 B$ ) and macrophages (Fig. $4 C$ ) revealed that a rather thin layer of smooth muscle cells is present predominantly in the upper region of intimal lesions while macrophages are distributed across the entire lesion. Both single staining for ScRs (Fig. $4 A$ ) and double staining (Fig. $4 E$ ) for ScRs (blue) and smooth muscle cells (red) showed that most ScR expressing cells were located toward the bottom layer of the intimal lesion where macrophages were abundant and smooth muscle cells were rarely detected by $\alpha$-actin staining. A higher power view of an area towards the bottom of the intimal lesion in the doublestained section (Fig. $4 F$ ) reveals that a few cells expressed both ScRs and $\alpha$-actin but most ScR-expressing cells (blue only) are apparently macrophages as judged by their morphology (round shaped foam cells) and nonreactivity with $\alpha$-actin. T cells are occasionally detected within the intimal lesions (Fig. $4 \mathrm{D}$ ). No obvious differences in the number or distribution pattern of $\mathrm{T}$ cells were observed in the intimal lesions of aortas taken from injured versus non-injured hypercholesterolemic rabbits.

ScR expression in balloon-injured aortas of normocholesterolemic rabbits. Fig. 5 shows representative stainings of serial sections obtained from balloon-injured aortas ( $10 \mathrm{~d}$ after injury) of normocholesterolemic rabbits. As with the staining patterns seen in hypercholesterolemic rabbits, non-immune goat antiserum yielded no specific staining (Fig. $5 A$ ). While some cells in the neointimal lesions expressed the $\mathrm{ScR}$, there appeared to be fewer $\mathrm{ScR}$ positive cells in the normocholesterolemic rabbits than in the hypercholesterolemic animals (Fig. $5 B$, and see Figs. $2 B, 3 A$, and $4 A$ ). Lesions produced by balloon injury in normocholesterolemic rabbits contained more smooth muscle cells and fewer macrophages than in the hypercholesterolemic rabbits (Fig. 5, $C-D$, and see Figs. 2-4). At higher magnification, most ScR-expressing cells have the typical spindle shape of smooth muscle cells (Fig. $5 E$ ), distinct from the shape of macrophages (round cells with large nuclei; Fig. $5 F$ ). Sparsely distributed $\mathrm{T}$ cells can also be detected in the neointimal lesions in a pattern similar to that seen in the hypercholesterolemic rabbits (data not shown). Non-injured areas of aortas (thoracic aortas) from normocholesterolemic rabbits had no intimal lesions or ScR expression (data not shown). Sections from the other four rabbits in this group showed similar results.

Cytokine-inducible ScR expression by cultured rabbit aortic smooth muscle cells in vitro. To explore potential mechanisms that could account for smooth muscle cell ScR expression in vivo, we investigated the induction of ScR expression in smooth muscle cells in vitro by cytokines relevant to atherogenesis. Rabbit aortic smooth muscle cells were treated with IL-1 $\alpha$,
TNF- $\alpha$, IL-4, lipopolysaccharide (LPS), or IFN- $\gamma$. Northern blot analysis (Fig. 6) using total RNA isolated from these cells showed a low level of ScR mRNA expression under basal tissue culture conditions. Treatment of the smooth muscle cells with TNF- $\alpha(10 \mathrm{ng} / \mathrm{ml})$ and IFN- $\gamma(1,000 \mathrm{U} / \mathrm{ml})$ for $18 \mathrm{~h}$ increased the expression of ScR mRNA (5.6-fold increase by TNF- $\alpha$ and 2.9-fold increase by IFN- $\gamma$, as measured by densitometry) whereas IL-1, IL-4, and LPS did not significantly alter the message levels. In RNA isolated from TNF- $\alpha-$ and IFN- $\gamma$-treated smooth muscle cells, three bands of $1.8,2.8$, and $3.8 \mathrm{~kb}$ were detected with the cDNA probe as previously shown in phorbol ester treated rabbit smooth muscle cells (13). Treatment with TNF- $\alpha$ and IFN- $\gamma$ for $24 \mathrm{~h}$ also increased the expression of $\mathrm{ScR}$ protein in rabbit aortic smooth muscle cells as detected by immunohistochemical staining (Fig. 7, C-F). These cells expressed very little $\mathrm{ScR}$ protein under basal conditions, while they did express $\alpha$-actin in a pattern characteristic of cultured smooth muscle cells (Fig. 7, $A$ and $B$ ).

Cytokine-inducible AcLDL degradation activity. We further assessed the functional consequences of cytokine-induced ScR expression by studying the binding and degradation of AcLDL in smooth muscle cells treated with IL- $1 \alpha$, TNF- $\alpha$, IFN- $\gamma$, or phorbol esters (TPA, Fig. 8). Under basal tissue culture conditions, smooth muscle cells have a low level of AcLDL degradation activity that did not change significantly after treatment with IL-1. However, treatment with TNF- $\alpha$ or IFN- $\gamma$ increased the AcLDL degradation activity to a similar (in the case of IFN$\gamma$ treatment) or even higher (in the case of TNF- $\alpha$ treatment) level than that seen with phorbol ester-stimulated rabbit smooth muscle cells. Competition experiments showed that the AcLDL degradation activity induced by TNF- $\alpha$ and IFN- $\gamma$ was ScR mediated, as unlabeled AcLDL, but not native LDL, blocked this process.

\section{Discussion}

During atherogenesis, certain subpopulations of smooth muscle cells proliferate and/or undergo morphological and functional modulation $(19,20)$. Such phenotypically altered smooth muscle cells exhibit features not shared by normal medial smooth muscle cells (39). Pitas et al. $(27,40)$ have shown in vitro that rabbit fibroblasts and smooth muscle cells inducibly express macrophage ScRs and that the enhanced ScR activity in these cells can also result in lipid accumulation and foam cell formation in culture. Bickel and Freeman (13) used phorbol ester treated rabbit smooth muscle cells to clone cDNAs encoding type I and type II ScRs and found that they represented the rabbit homologues of the macrophage ScR. In addition, Jaakola and Nikkari (41) have demonstrated that a fluorescently sorted population of rabbit smooth muscle cells, isolated from the aortas of cholesterol-fed rabbits, varied dramatically with respect to ScR activity. These studies suggested that ScR mediated uptake of modified LDL may contribute to the generation of foam cells from smooth muscle cells that reside within atherosclerotic lesions.

We used balloon injury in this study because this treatment produces intimal lesions richer in smooth muscle cells than does the consumption of an atherogenic diet alone. The more fibrous lesions produced by balloon injury resemble human atheroma more closely than the macrophage-rich lesions observed in uninjured arteries of hypercholesterolemic rabbits. Only a few 

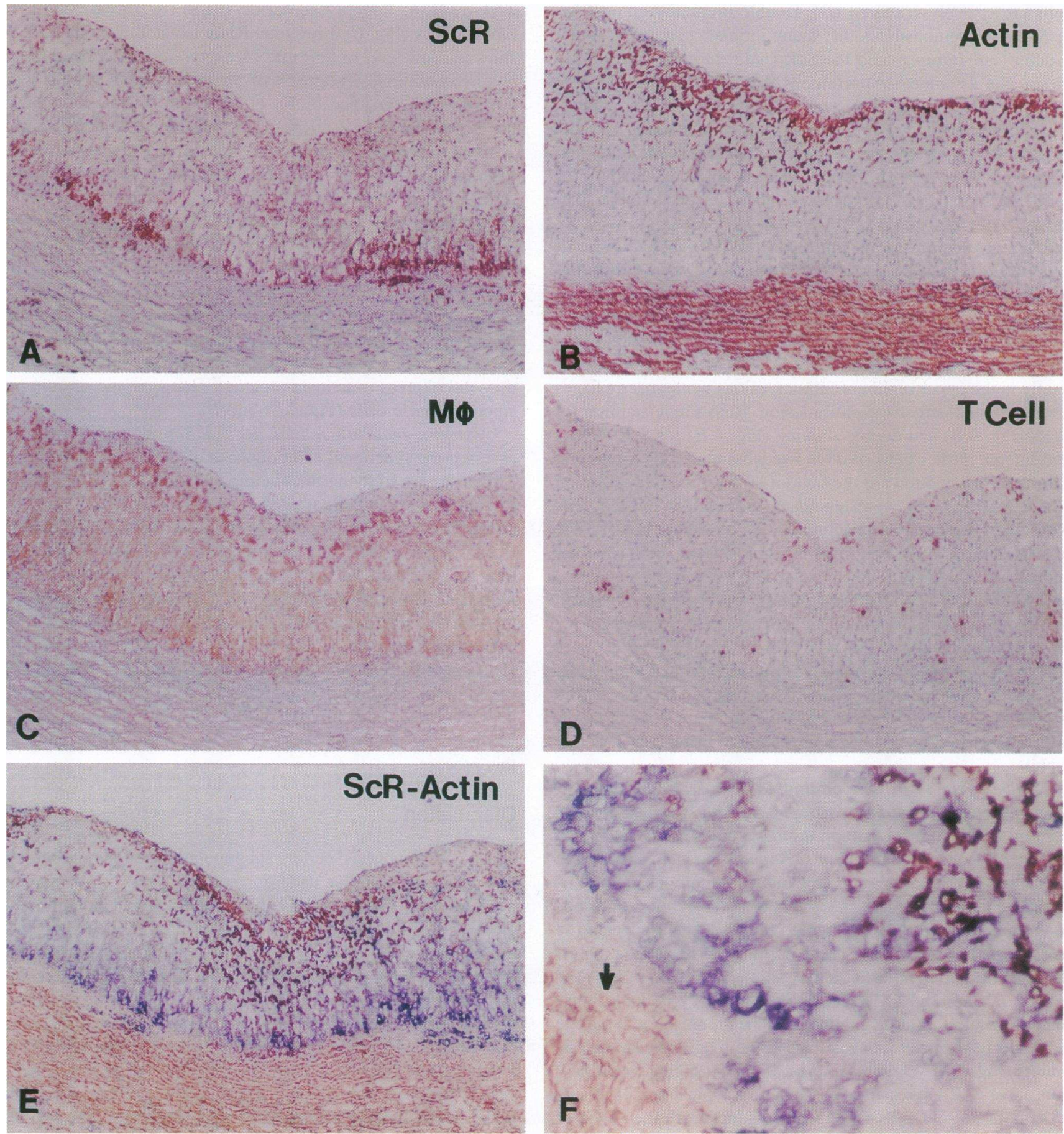

Figure 4. Single and double immunostaining of serial sections from the non-injured area (ascending aorta) of a hypercholesterolemic rabbit. Immunoperoxidase stainings shows that ScRs are located mainly at the bottom layer of the intimal lesion $(A)$ where macrophages were abundant $(C)$ and smooth muscle cells were rarely detected by $\alpha$-actin staining $(B)$. X100. T cells were detected spread sparsely throughout the intimal lesion $(D)$. X100. Double staining ( $E, \mathrm{X} 100$; and $F, \mathrm{X} 200)$ for ScR (blue) and smooth muscle cells (red) showed a few ScR expressing smooth muscle cells (mixed staining of blue and red) and abundant ScR expressing macrophages (judged by their morphology and the non-reactivity with $\alpha$-actin, i.e., cells with blue staining only). Arrow in $F$ indicates internal elastic lamina.

smooth muscle cells, in the intimal lesions produced by balloon injury alone, expressed ScRs. However, many smooth muscle cells expressed the ScR if a hypercholesterolemic diet was employed, both in the injured and non-injured aortic intima. A subpopulation of ScR-expressing macrophages can also be detected in both injured and non-injured aortas of hypercholesterolemic rabbits, while not many such cells are seen in the injuryinduced neointimal lesions of normocholesterolemic rabbits. 

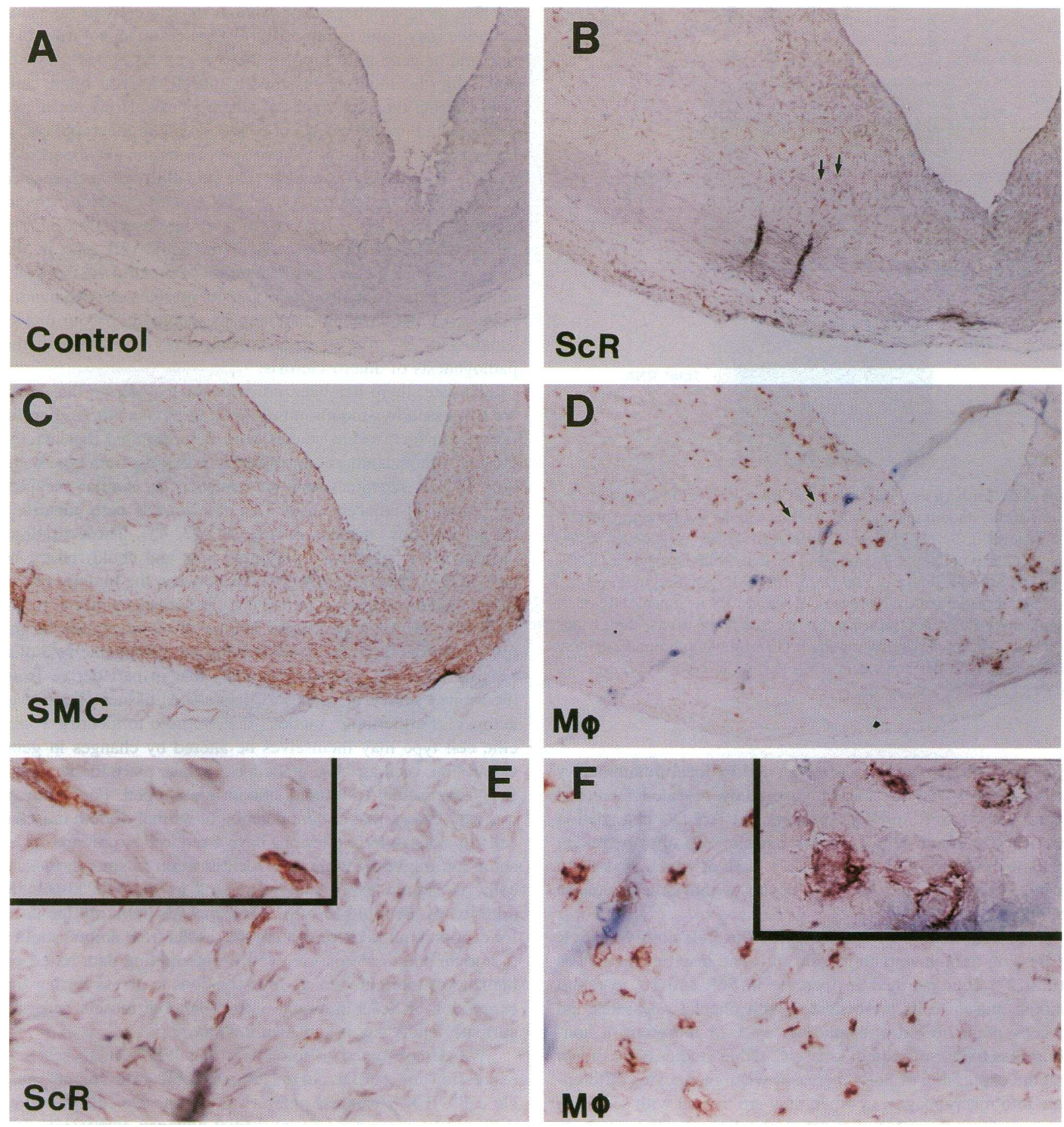

Figure 5. Immunoperoxidase staining for ScR expression and cell type identification markers in serial sections from the balloon-injured aorta of a normocholesterolemic rabbit. $(A)$ Non- immune goat serum yielded no specific staining. X100. $(B)$ Antibody against ScR stained positively a few cells in the neointimal lesion. X100. (C) Staining with $\alpha$-actin showed the presence of abundant smooth muscle cells in the neointima. X100. $(D)$ Antibody RAM-11 detected some macrophages in the neointima. X100. ( $E$ and $F$ ) Higher power view of stainings for ScR and macrophages located in the arrow denoted regions of $B$ and $D$. Most ScR expressing cells have the typical spindle shape of smooth muscle cells $(E)$ distinct from the morphology of macrophages which are round cells with large nuclei $(F) . \mathrm{X} 1,000$ in the insert and $\mathrm{X} 400$ in the other areas.

The mechanism underlying these differences is unclear, but a growing body of evidence suggests that hypercholesterolemia itself can induce changes in gene expression in vascular cells and that such changes may be required for high level expression of the ScR. As intimal lesions in the aorta of hyperlipidemic rabbits are rich in activated macrophages and $\mathrm{T}$ lymphocytes, there is sufficient opportunity for exposure of smooth muscle cells to the wide variety of growth factors and cytokines produced by these inflammatory cells. Thus, it seems likely that hyperlipidemia could alter smooth muscle cell gene expression 


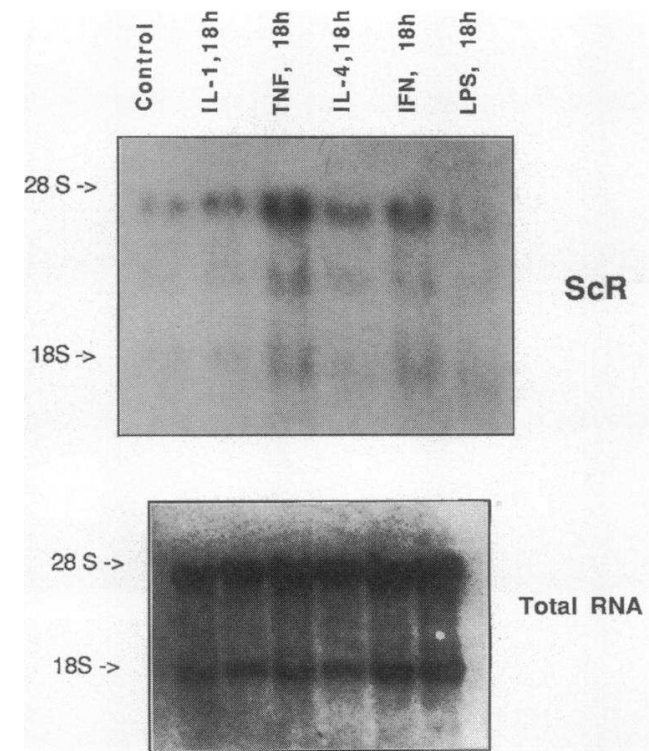

Figure 6. Northern analysis using total RNA isolated from cultured rabbit aortic smooth muscle cells with or without cytokine treatment. A low level of ScR mRNA was expressed by these cells under basal tissue culture conditions. Treatment of the cells with the cytokines TNF$\alpha(10 \mathrm{ng} / \mathrm{ml})$ and IFN- $\gamma(1,000 \mathrm{U} / \mathrm{ml})$ for $18 \mathrm{~h}$ increased the level of expression of ScR mRNA whereas IL-1 and LPS treatment did not significantly alter levels (upper panel, the ScR probe detects three bands in rabbit SMC as previously reported) (13). Ethidium bromide staining of total RNA verifies equivalent RNA loading in each lane (lower panel).

directly or via paracrine factors secreted by local inflammatory cells $(42,43)$. Indeed, our in vitro study revealed increased expression of ScR mRNA, protein, and AcLDL degradation activity in cultured aortic smooth muscle cells after treatment with the cytokines TNF- $\alpha$ and IFN- $\gamma$, both of which are known to be secreted by activated leukocytes within atherosclerotic lesions.

Previous studies have established the inducibility of ScR expression in both smooth muscle cells and macrophages. Pitas et al. (27) demonstrated an increase in ScR activity in rabbit smooth muscle cells preincubated with platelet releasates and in cells preincubated with phorbol ester or mezerein, a nonphorbol activator of protein kinase C. Other studies have shown that the expression of ScRs increases when monocytes differentiate into macrophages, or when they are treated with secretion products from thrombin-stimulated platelets, phorbol esters, or macrophage colony stimulating factor (M-CSF) (22-24). In contrast to these effects, Geng and Hansson et al. reported that recombinant IFN- $\gamma$ or IFN- $\gamma$-containing lymphocyte culture media inhibits the expression of ScR mRNA, protein and AcLDL degradation as well as foam cell formation, in human monocyte-derived macrophages (25). Similarly, several investigators found that IFN- $\gamma$ inhibits AcLDL degradation in activated murine macrophages $(26,44)$. To our surprise, we found that in rabbit smooth muscle cells, IFN- $\gamma$ increased the expression of both ScR mRNA and protein. The IFN- $\gamma$ induced ScR expression is accompanied by an increase in AcLDL degradation activity to a level as high as that seen in phorbol esterstimulated cells. These apparently divergent transcriptional re- sponses of macrophages and smooth muscle cells to the same cytokine may point to important differences in signal transduction and/or gene regulation in the two cell types and may account for the increase in smooth muscle-derived foam cells noted during the later stages of atherogenesis. However, as we did not examine the effects of IFN- $\gamma$ on rabbit macrophages, it is possible that cytokine-induced ScR expression may be species as well as cell-type dependent. The possibility of such species differences in the expression of ScRs, or in cytokine responsiveness, preclude the generalization of our observations in rabbit aortic smooth muscle cells to the same cell type in the human or other species. Further studies comparing the cytokineinducible expression of ScRs in smooth muscle cells and macrophages from both rabbits and humans should clarify our understanding of the role of these inflammatory molecules in the pathogenesis of atherosclerosis.

To date, there has been no evidence to indicate that ScRs are expressed by smooth muscle cells in human atherosclerotic lesions. In fact, recent studies have demonstrated that macrophages in human atherosclerotic lesions express both type I and type II ScR receptors without evidence for similar receptor expression in adjacent intimal smooth muscle cells identified by an antibody against $\alpha$-actin $(16,17,45)$. These findings clearly differ from those presented here and could reflect, as stated above, important differences between the biology of the rabbit models of atherosclerosis and the human condition. However, the chronic and complex nature of atherogenesis in humans imposes limitations on studying the pathogenic role of a specific molecule (such as the ScR) that in part derive from the limited source of tissues available (i.e., tissues obtained at autopsy). Furthermore, markers that are used to identify a specific cell type may themselves be altered by changes in gene expression, such as those that appear to take place in the transition from medial to intimal smooth muscle cell. For instance, it is well known that a subpopulation of intimal smooth muscles cells in atherosclerotic lesions have a reduced expression of $\alpha$ actin that might preclude their identification as smooth muscle cells, if $\alpha$-actin expression were used as the sole histologic criterion of identity (46-48). These caveats point out the need for caution both in extrapolating the results from animal studies to human atherosclerosis as well in interpreting data based on human postmortem studies. Investigations to assess further the expression of ScRs in human intimal smooth muscle cells are currently underway in our own laboratory.

We demonstrated in this study that IFN- $\gamma$ increases ScR expression and AcLDL degradation in rabbit aortic smooth muscle cells. IFN- $\gamma$ can also inhibit smooth muscle cell proliferation, decrease $\alpha$-actin and interstitial collagen expression, and increase the expression of VCAM-1, a mononuclear leukocyte adhesion molecule, in this cell type (49-51). Taken together, these observations suggest that IFN- $\gamma$, a product of activated T cells, may play an important role in the phenotypic modulation of smooth muscle cells in atherosclerotic lesions. The possible involvement of IFN- $\gamma$ in regulation of ScR expression further highlights the important and complex role of $\mathrm{T}$ lymphocytes in atherosclerotic lesions. Previous studies have revealed that $T$ lymphocytes reside in atherosclerotic lesions and that many of these $\mathrm{T}$ cells are in a chronically activated state, as evidenced by their production of IFN- $\gamma(2,52,53)$. Our study confirmed the presence of $T$ cells in the intimal lesions of both injured and non-injured aortas from hypercholesterolemic rabbits as 

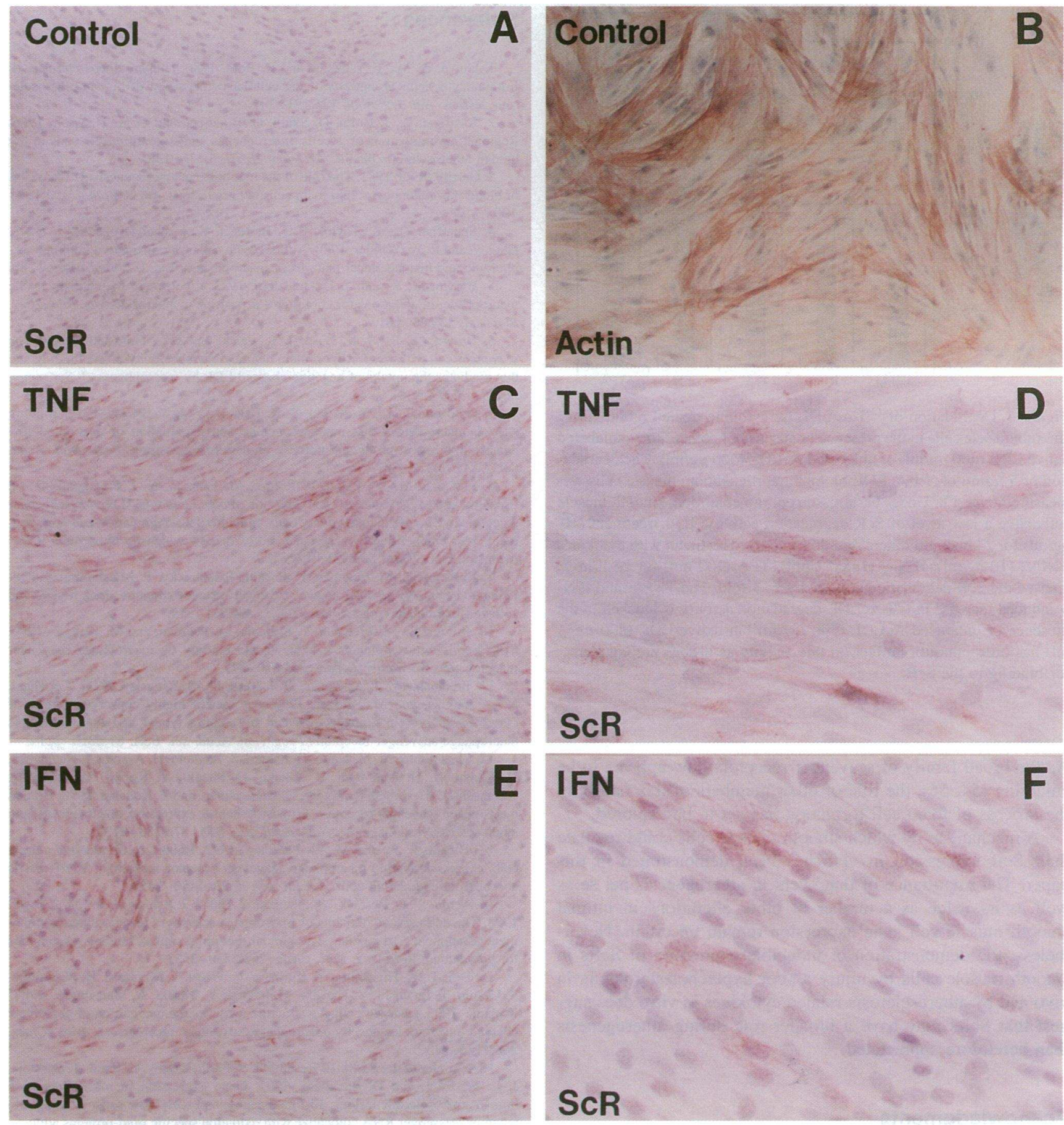

Figure 7. Immunohistochemical staining for ScR expression by rabbit aortic smooth muscle cells plated on tissue culture slides. $(A)$ Very little ScR expression can be detected in cells cultured in control medium. X100. $(B) \alpha$-actin staining reveals a cytoskeletal staining pattern characteristic of smooth muscle cells. X100. (C) Incubation with medium containing TNF- $\alpha(10 \mathrm{ng} / \mathrm{ml})$ for $24 \mathrm{~h}$ induced ScR expression in many cells. X100. $(D)$ High power view of TNF- $\alpha$-induced ScR expression. X600. (E) IFN- $\gamma(1,000 \mathrm{U} / \mathrm{ml}, 24 \mathrm{~h})$-induced ScR expression in cultured rabbit aortic smooth muscle cells. X100. $(F)$ High power view of IFN- $\gamma$ induced ScR expression. X600.

well as in the injury-induced lesions of normocholesterolemic animals. Although there appeared to be more $T$ cells in areas of high ScR expression by intimal smooth muscle cells (Fig. 3 $D$ and $4 D$ ), the sparse distribution pattern and paucity of $T$ cells in the lesions do not permit us to draw conclusions on the spatial correlation of $\mathrm{T}$ cell and ScR expression or to make any meaningful quantitative conclusions as to differing numbers of $\mathrm{T}$ cells in injured and non-injured aortas. Further investigations will be required to clarify the role of $T$ cells and their cytokine products in the regulation of ScR expression. Further work will also be required to determine if the activity of macrophage ScRs is sufficient to account for smooth muscle foam cell formation. 


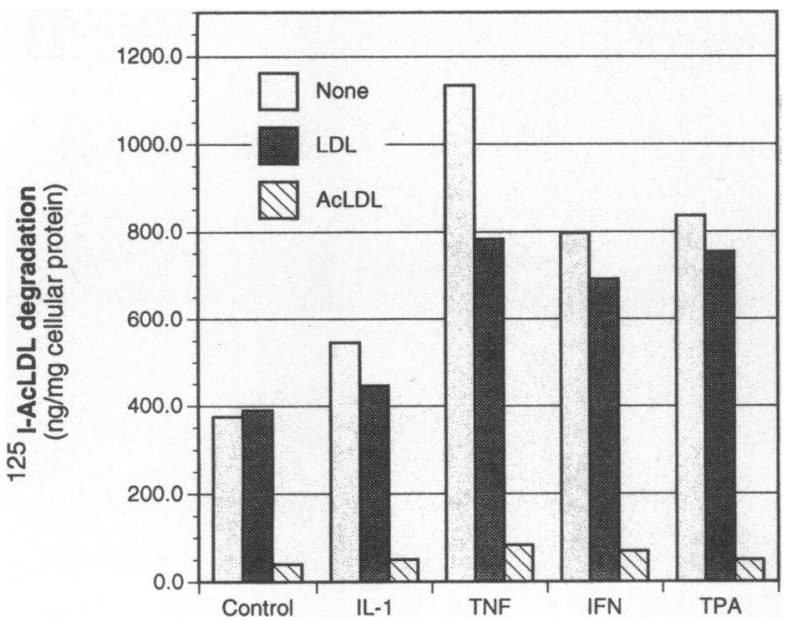

Figure 8. Degradation of ${ }^{125} \mathrm{I}$-AcLDL by cytokine treated rabbit aortic smooth muscle cells in the presence or absence of competitors. unlabeled native LDL $(400 \mu \mathrm{g} / \mathrm{ml})$ or unlabeled AcLDL $(400 \mu \mathrm{g} / \mathrm{ml})$. The degradation of $5 \mu \mathrm{g} / \mathrm{ml}$ of ${ }^{125} \mathrm{I}$-AcLDL by rabbit aortic smooth muscle cells was measured over $5 \mathrm{~h}$. Under basal tissue culture condition, smooth muscle cells have a low level of ScR degradation activity. IL-1 treatment (10 $\mathrm{ng} / \mathrm{ml}$ ) for $24 \mathrm{~h}$ slightly increased this activity. Treatment with cytokines TNF- $\alpha(10 \mathrm{ng} / \mathrm{ml})$, IFN- $\gamma(1,000 \mathrm{U} / \mathrm{ml})$, TPA $(100 \mathrm{~nm})$ for $24 \mathrm{~h}$ increased the ScR degradation activity by 2-3-fold. The TNF- $\alpha$ and IFN$\gamma$ induced increase in ${ }^{125} \mathrm{I}$-AcLDL degradation activity is blocked in the presence of unlabeled AcLDL ( $400 \mu \mathrm{g} / \mathrm{ml})$ but native LDL (400 $\mu \mathrm{g} /$ $\mathrm{ml}$ ) has little inhibitory effect on this activity as it does not compete for binding to the ScR.

As the broad family of scavenger receptors now appears to be enlarging $(54,55)$, the role of other members of this family in the process of foam cell formation has yet to be explored.

A mechanism by which smooth muscle cells could regulate their ScR expression in vivo has been demonstrated in this paper. The importance of that event in atherogenesis per se as well as its value as a marker of other alterations in intimal smooth muscle cell gene expression remain uncertain. Nevertheless, the demonstration of inducible expression of ScRs in smooth muscle cells by injury and/or hypercholesterolemia in vivo and by atherosclerosis-related cytokines in vitro does suggest that ScRs may have a broader role during atherogenesis than heretofore appreciated.

\section{Acknowledgments}

We thank Drs. Alan Shaw for the gift of rabbit recombinant IL-1 $\alpha$, Edward Amento of Genentech for rabbit recombinant IFN- $\gamma$, and Richard Ulevitch of Scripps Clinic and Research Foundation for recombinant rabbit TNF- $\alpha$. We appreciate the support of Dr. Myron Cybulsky and the technical assistance provided by Maria Muszunski, Hiroyuki Tanaka, Galina K. Sukhova, George Stavrakis, and Lorna Andersson for this study.

This work is supported by National Heart, Lung and Blood Institute grants PO-1-HL-48743 (incorporating HL-47840) to P. Libby and HL45098 to M. W. Freeman, as well as an American Heart Association national grant-in-aid award (to $M$. W. Freeman). Hongmei $L i$ is a recipient of the National Research Service Awards for Individual Postdoctoral Fellows.

\section{References}

1. Gown, A. M., T. Tsukada, and R. Ross. 1986. Human atherosclerosis. II. Immunocytochemical analysis of the cellular composition of human atherosclerotic lesions. Am. J. Pathol. 125:191-207.

2. Jonasson, L., J. Holm, O. Skalli, G. Bondjers, and G. K. Hansson. 1986. Regional accumulations of $\mathrm{T}$ cells, macrophages and smooth muscle cells in the human atherosclerotic plaque. Arteriosclerosis. 6:131-138.

3. Gerrity, R. G. 1981. The role of the monocyte in atherogenesis. I. Transition of blood- born monocytes into foam cells in fatty lesions. Am. J. Pathol. 103:181 190.

4. Schaffner, T., K. Taylor, E. J. Bartucci, K. Fischer-Dzoga, B. J. H., S Glagov, and R. W. Wissler. 1980. Arterial foam cells with distinctive immunomorphologic and histochemical features of macrophages. Am. J. Pathol. 100:57-80.

5. Brown, M. S., and J. L. Goldstein. 1983. Lipoprotein metabolism in the macrophage: implications for cholesterol deposition in atherosclerosis. Annu. Rev. Biochem. 52:223-261.

6. Brown, M. S., S. K. Basu, J. R. Falck, and J. L. Goldstein. 1980. The scavenger cell pathway for lipoprotein degradation: specificity of the binding site that mediates the uptake of negative-charged LDL by macrophages. J. Supramol. Struct. 13:67-81.

7. Goldstein, J. L., Y. K. Ho, S. K. Basu, and M. S. Brown. 1979. Binding site on macrophages that mediates uptake and degradation of acetylated low density lipoprotein producing massive cholesterol deposition. Proc. Natl. Acad. Sci. USA. 76:333-337.

8. Freeman, M., Y. Ekkel, L. Rohrer, M. Penman, N. J. Freedman, G. M. Chisolm, and M. Krieger. 1991. Expression of type I and type II bovine scavenger receptors in Chinese hamster ovary cells: lipid droplet accumulation and nonreciprocal cross competition by acetylated and oxidized low density lipoprotein. Proc. Natl. Acad. Sci. USA. 88:4931-4935.

9. Kodama, T., M. Freeman, L. Rohrer, J. Zabrecky, P. Matsudaira, and M Krieger. 1990. Type I macrophage scavenger receptor contains alpha-helical and collagen-like coiled coils. Nature (Lond.). 34:531-535.

10. Rohrer, L., M. Freeman, T. Kodama, M. Penman, and M. Krieger. 1990 Coiled-coil fibrous domains mediate ligand binding by macrophage scavenge receptor type II. Nature (Lond.). 343:570-572.

11. Freeman, M., J. Ashkenas, D. J. Rees, D. M. Kingsley, N. G. Copeland, N. A. Jenkins, and M. Krieger. 1990. An ancient highly conserved family of cysteine-rich protein domains revealed by cloning type I and type II murine macrophage scavenger receptors. Proc. Natl. Acad. Sci. USA. 87:8810-8814.

12. Matsumoto, A., M. Naito, H. Itakura, S. Ikemoto, H. Asaoka, I. Hayakawa H. Kanamori, H. Aburatani, F. Takaku, H. Suzuki, Y. Kobari, T. Miyai, K Takahashi, E. H. Cohen, R. Wydro, D. E. Housman, and T. Kodama. 1990. Human macrophage scavenger receptors: Primary structure, expression, and localization in atherosclerotic lesions. Proc. Natl. Acad. Sci. USA. 87:9133-9137.

13. Bickel, P. E. and M. W. Freeman. 1992. Rabbit aortic smooth muscle cells express inducible macrophage scavenger receptor messenger RNA that is absent from endothelial cells. J. Clin. Invest. 90: 1450-1457.

14. Acton, S., D. Resnick, M. Freeman, Y. Ekkel, J. Ashkenas, and M. Krieger. 1993. The collagenous domains of macrophage scavenger receptors and complement component $\mathrm{Clq}$ mediate their similar, but not identical, binding specificities for polyanionic ligands. J. Biol. Chem. 268:3530-3537.

15. Doi, T., K. Higashino, Y. Kurihara, Y. Wada, T. Miyazaki, H. Nakamura, S. Uesugi, T. Imanishi, Y. Kawabe, H. Itakura, Y. Yazaki, A. Matsumoto, and T. Kodama. 1993. Charged collagen structure mediates the recognition of negatively charged macromolecules by macrophage scavenger receptors. J. Biol. Chem. 268:2126-2133.

16. Yla-Herttuala, S., M. E. Rosenfeld, S. Parthasarathy, E. Sigal, T. Sarkioja, J. L. Witztum, and D. Steinberg. 1991. Gene expression in macrophage-rich human atherosclerotic lesions: 15-lipoxygenase and acetyl low density lipoprotein receptor messenger RNA colocalize with oxidation specific lipid-proteins adducts. J. Clin. Invest. 87:1146-1152.

17. Naito, M., H. Suzuki, T. Mori, A. Matsumoto, T. Kodama, and K. Takahashi. 1992. Coexpression of type I and type II human macrophage scavenger receptors in macrophages of various organs and foam cells in atherosclerotic lesions. Am. J. Pathol. 141:591-599.

18. Ashkenas, J., M. Penman, E. Vasile, S. Acton, M. Freeman, and M. Krieger. 1993. Structures and high and low affinity ligand binding properties of murine type I and type II macrophage scavenger receptors. J. Lipid Res. 34:9831000.

19. Mosse, P. R., G. R. Campbell, Z. L. Wang, and J. H. Campbell. 1985. Smooth muscle cell phenotype expression in human carotid arteries: I. comparison of cells from diffuse intimal thickenings adjacent to atheromatous plaque with those of media. Lab. Invest. 53:556-562.

20. Mosse, P. R., G. R. Campbell, and J. H. Campbell. 1986. Smooth muscle cell phenotype expression in human carotid arteries. II. Atherosclerosis-free diffuse intimal thickenings compared with the media. Arteriosclerosis. 6:664-669.

21. Pitas, R. E., T. L. Innerarity, and R. W. Mahley. 1983. Foam cells in 
explants of atherosclerotic rabbit aortas have receptors for $\beta$-very low density lipoproteins and modified low density lipoproteins. Arteriosclerosis. 3:2-12.

22. Inaba, T., N. Yamada, T. Gotoda, H. Shimano, M. Shimada, K. Monomura, T. Kadowaki, K. Motoyoshi, T. Tsukaka, N. Morisaki, Y. Saito, S. Yoshida, F. Takaku, and Y. Yazaki. 1992. Expression of M-CSF receptor encoded by cfms on smooth muslce cells derived from arteriosclerotic lesion. J. Biol. Chem. 267:5693-5699.

23. Fogelman, A. M. M. E. Haberland, J. Seager, M. Hokom, and P. A. Edwards. 1981. Factors regulating the activities of the low density lipoprotein receptor and the scavenger receptor on human monocyte-macrophages. J. Lipid Res. 22:1131-1141.

24. Clinton, S. K., R. Underwood, L. Hayes, M. L. Sherman, D. W. Kufe, and P. Libby. 1992. Macrophage colony-stimulating factor gene expression in vascular cells and in experimental and human atherosclerosis. Am. J. Pathol. 140 (2):301-316

25. Geng, Y., and G. K. Hansson. 1992. Interferon- $\gamma$ inhibits scavenger receptor expression and foam cell formation in human monocyte-derived macrophages. J. Clin. Invest. 89:1322-1330.

26. Fong, L. G., A. T. Fong, and A. D. Cooper. 1990. Inhibitions of mouse macrophage degradation of acetyl-low density lipoproteins by interferon- $\gamma$. J. Biol. Chem. 265:11751-11760.

27. Pitas, R. E. 1990. Expression of the acetyl low density lipoprotein receptor by rabbit fibroblasts and smooth muscle cells: Up-regulation by phorbol esters. J. Biol. Chem. 265:12722-12727.

28. Tanaka, H., G. K. Sukhova, S. J. Swanson, S. K. Clinton, P. Ganz, M. I. Cybulsky, and P. Libby. 1993. Sustained activation of vascular cells and leukoctyes in the rabbit aorta after balloon injury. Circulation. 88:1788-1803.

29. Libby, P., and K. V. O'Brien. 1983. Culture of quiescent vascular smooth muscle cells in a defined serum-free medium. J. Cell Physiol. 115:217-223.

30. Warner, S. J. C., K. R. Auger, and P. Libby. 1987. Interleukin-1 induces interleukin-1. II. Recombinant human interleukin-1 induces interleukin-1 production by adult human vascular endothelial cells. J. Immunol. 139:1911-1917.

31. Tsukada, T., D. Tippens, D. Gordon, R. Ross, and A. M. Gown. 1987. HHF35, A muscle-actin-specific monoclonal antibody. Am. J. Pathol. 127:5160 .

32. Tsukada, T., M. Rosenfeld, R. Ross, and A. M. Gown. 1986. Immunocytochemical analysis of cellular components in lesions of atherosclerosis in the Watanabe and fat-fed rabbit using monoclonal antibodies. Arteriosclerosis. 6:601-613.

33. Hodges, R. S., R. J. Heaton, J. M. Parker, L. Molday, and R. S. Molday. 1988. Antigen-antibody interaction. Synthetic peptides define linear antigenic determinants recognized by monoclonal antibodies directed to the cytoplasmic carboxyl terminus of rhodopsin. J. Biol. Chem. 263:11768-11775.

34. Cybulsky, M. I., and M. A. J. Gimbrone. 1991. Endothelial expression of a mononuclear leukocyte adhesion molecule during atherogenesis. Science (Wash. DC). 251:788-791.

35. Li, H., M. I. Cybulsky, M. A. J. Gimbrone, and P. Libby. 1993. An atherogenic diet rapidly induces VCAM-1, a cytokine-regulatable mononuclear leukocyte adhesion molecule, in rabbit aortic endothelium. Arteriosclerosis. 13:197-204.

36. Maniatis, T., E. F. Fritsch, and J. Sambrook. 1989. Molecular Cloning. A Laboratory Manual. Cold Spring Harbor Laboratories, Cold Spring Harbor, New York.

37. Krieger, M. 1983. Complementation of mutations in the LDL pathway of receptor-mediated endocytosis by cocultivation of $\mathrm{LDL}$ receptor-defective hamster cell mutant. Cell. 33:413-422.

38. Bilheimer, D. W., S. Eisenberg, and R. I. Levy. 1972. The metabolism of very low density lipoproteins. I. Preliminary in vitro and in vivo observations. Biochim. Biophys. Acta. 260:212-221.

39. Daniel-Lamaziere, J. M., A. Desmouliere, M. Pascal, and J. Larrue. 1988. Detection of atherosclerotic plaque with two monoclonal antibodies. 2P1A2 monoclonal antibody is specific for smooth muscle cells in atherosclerotic plaque. Arteriosclerosis. 74:115-126.

40. Pitas, R. E., A. Friera, J. McGuire, and S. Dejager. 1992. Further characterization of the acetyl LDL (scavenger) receptor expressed by rabbit smooth muscle cells and fibroblasts. Arteriosclerosis. 12:1235-1244.

41. Jaakkola, O., and T. Nikkari. 1990. Lipoprotein degradation and cholesterol esterification in primary cell cultures of rabbit atherosclerotic lesions. Am. J. Pathol. 132:457-465.

42. Libby, P., D. Schwartz, E. Brogi, H. Tanaka, and S. K. Clinton. 1992. A cascade model for restenosis, a special case of atherosclerosis progression. Circulation. 86:47-52.

43. Libby, P., and G. K. Hansson. 1991. Involvement of the immune system in human atherogenesis: current knowledge and unanswered questions. Lab. Invest. 64:5-12.

44. Kraemer, F. B., R. K. Tavangar, G. R. K., K. Kirlew, and S. R. Behr. 1990. Effects of activation on lipid and lipoprotein metabolism in murine macrophages. Arteriosclerosis. 10:8-16.

45. Luoma, J., T. Hiltunen, T. Sarkioja, S. K. Moestrup, J. Gliemann, T. Kodama, T. Nikkari, and S. Yla-Herttuala. 1994. Expression of alpha 2-macroglobulin receptor/low density lipoprotein-related protein and scavenger receptor in human atherosclerotic lesions. J. Clin. Invest. 93:2014-2021.

46. Gabbiani, G., O. Kocher, W. S. Bloom, J. Vandekerckhove, and K. Weber. 1984. Actin expression in smooth muscle cells of rat aortic intimal thickening, human atheromatous plaque, and cultured rat aortic media. J. Clin. Invest. 73:148152.

47. Kocher, O., and G. Gabbiani. 1987. Analysis of $\alpha$-smooth-muscle actin mRNA expression in rat aortic smooth-muscle cells using a specific cDNA probe. Differentiation. 34:201-209.

48. Babaev, V. R., Y. V. Bobryshev, O. V. Stenina, E. M. Tararak, and G. Gabbiani. 1990. Heterogeneity of smooth muscle cells in atheromatous plaque of human aorta. Am. J. Pathol. 136: 1031-1042.

49. Warner, S. J. C., G. B. Friedman, and P. Libby. 1989. Immune interferon inhibits proliferation and induces 2'-5'-oligoadenylate synthetase gene expression in human vascular smooth muscle cells. J. Clin. Invest. 83:1174-1182.

50. Hansson, G. K., M. Hellstrand, L. Rymo, L. Rubbia, and G. Gabbiani. 1989. Interferon- $\gamma$ inhibits both proliferation and expression of differentiationspecific $\alpha$-smooth muscle actin in arterial smooth muscle cells. J. Exp. Med. 170:1595-1608.

51. Li, H., M. I. Cybulsky, M. A. J. Gimbrone, and P. Libby. 1993. Inducible expression of vascular cell adhesion molecule 1 by vascular smooth muscle cells in vitro and within rabbit atheroma. Am. J. Pathol. 143:1551-1559.

52. Hansson, G. K., J. Holm, and L. Jonasson. 1989. Detection of activated T lymphocytes in the human atherosclerotic plaque. J. Clin. Invest. 76:125-131.

53. Jonasson, G. K., J. Holm, O. Skalli, G. Gabbiani, and G. K. Hansson. 1985. Expression of class II transplantation antigen on vascular smooth muscle cells in human atherosclerosis. J. Clin. Invest 76:1174-1128.

54. Endemann, G., L. W. Stanton, K. S. Madden, C. M. Bryant, R. T. White, and A. A. Protter. 1993. CD 36 is a receptor for oxidized low density lipoprotein. J. Biol. Chem. 268:11811-11816.

55. Acton, S. L., P. E. Scherer, H. F. Lodish, and M. Krieger. 1994. Expression cloning of SR-BI, a CD36-related Class B scavenger receptor. J. Biol. Chem. 269:21003-21009. 